\title{
SOLUBILISATION OF (+)-USNIC ACID IN AQUEOUS MICELLAR SOLUTIONS OF GEMINI AND HETEROGEMINI SURFACTANTS AND THEIR EQUIMOLAR MIXTURE
}

\author{
Lukáč, M. - Prokipčák, I. - Lacko, I. - Devínsky, F. \\ Comenius University in Bratislava, Faculty of Pharmacy, \\ Department of Chemical Theory of Drugs
}

\begin{abstract}
The solubilisation of natural compound, (+)-usnic acid, in micellar solutions of gemini ( $N, N^{\prime}$-didecyl- $N, N, N^{\prime}, N^{\prime}$-tetramethylethane-1,2-diyldiammonium dibromide) and heterogemini (decyl 2-[decyl(dimethyl)ammonio]ethylphosphate) surfactants and their equimolar mixture has been studied. The highest solubility was found for gemini surfactant. The relationship between synergism in surface properties of mixture of surfactants and their solubilisation properties is also discussed.
\end{abstract}

Keywords: gemini surfactant - heterogemini surfactant-usnic acid - solubilisation -solubility in aqueous solutions

\section{INTRODUCTION}

Usnic acid (Figure 1) is a phenolic compound. It is an optically active derivative of dibenzofurane and both enantiomers can be found in lichens. It is the constituent of many genera, e.g., Usnea (Cansaran et al., 2006, Lukáč, 2010), Cladonia (Ingólfsdóttir et al., 1998), Ramalina (Tay et al., 2004), or Alectoria (Einarsdóttir et al., 2010).<smiles>CC(=O)C1=C(O)C=C2Oc3c(C(C)=O)c(O)c(C)c(O)c3C2(C)C1=O</smiles>

Figure $1(+)$-Usnic acid 
This lichen acid has a wide spectrum of biological activities. It possesses antibacterial, antifungal, antimycobacterial (Ingólfsdóttir, 2002, Melgarejo et al., 2008, Ranković et al., 2008), antiparasitic (Cetin et al., 2008), and antineoplastic activities (Bačkorová et al., 2011, Bazin et al., 2008, Einarsdóttir et al., 2010).

The disadvantage of usnic acid is in its low solubility in aqueous solutions and it complicates its investigations in these media, e.g., microbiological testing. The micellar solubilisation with surfactants, cosolvents or complexation between usnic acid and cyclodextrines was used to increase lichen acid solubility in water solutions (Kristmundsdóttir et al., 2002, 2005; Lira et al., 2009; Segure-Sanchez et al, 2009).

The second disadvantage of usnic acid is its hepatotoxicity. Encapsulation of usnic acid can resolve the problems of hepatotoxicity and also of low solubility in water. Encapsulation of usnic acid into nanocapsules prepared from lactic co-glycolic acid polymer improved antitumour activity of this lichen acid and considerably reduced its hepatotoxicity. Moreover, the prepared suspensions of encapsulated usnic acid in aqueous environments are stable for several months (da Silva Santos et al., 2006).

Surfactants are very often used for solubilisation of sparingly soluble compounds. They can form micelles in aqueous solution and compounds can be solubilised in different parts of the aggregate. Hydrophilic compounds can be adsorbed on the surface of the micelle; compounds with intermediate hydrophilic properties are located in the palisade layer between the hydrophilic groups and the first few carbon atoms of the nonpolar groups; and hydrophobic compounds are situated in the inner core of the micelle (Rangel-Yagui et al., 2005). Different types of surfactants can be used in solubilisation of sparingly soluble compounds. They can be represented by anionic, cationic, zwitterionic or nonionic surfactants (Ullah et al., 2012).

The aim of this study was the investigation of the influence of a bisammonium salt, dialkylphosphocholine, and their equimolar mixture on the solubilisation of usnic acid in aqueous solutions. The bisammonium salt and dialkylphosphocholine (Figure 2) were chosen as representative dimeric surfactants. The bisammonium salt represents a cationic surfactant and dialkylphosphocholine represents a zwitterionic surfactant. This study is an extension of our previous work where we investigated the influence of these two surfactants on solubilisation of griseofulvin and rutin in aqueous solutions (Lukáč et al., 2011).

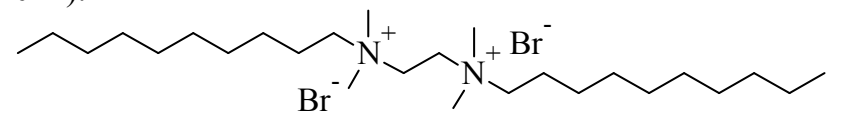

$N, N^{\prime}$-didecyl- $N, N, N^{\prime}, N^{\prime}$-tetramethylethane-1,2-diyldiammonium dibromide $(\boldsymbol{N})$

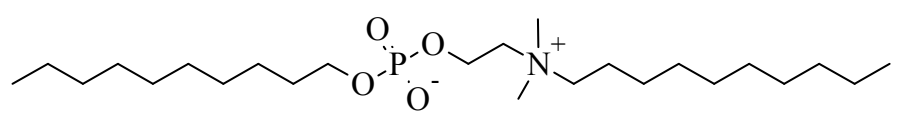

decyl [2-decyl(dimethyl)ammonio] ethylphosphate $(\boldsymbol{P})$

Figure 2 Structure of solubilisers 


\title{
MATERIALS AND METHODS
}

\author{
Surfactants \\ Decyl 2-[decyl(dimethyl)ammonio]ethylphosphate $(\boldsymbol{P})$ and $N, N^{\prime}$-didecyl- $N, N, N^{\prime}, N^{\prime}$ '- \\ tetramethylethane-1,2-diyldiammonium dibromide $(\boldsymbol{N})$ were prepared according \\ to the described procedure (Lukáč et al., 2009).

\section{Usnic acid} \\ Usnic acid was isolated from Usnea filipendula according to the modified procedure \\ described by Ingólfsdóttir et al. (1998). The specimens were collected in Veporské \\ Vrchy Mts., Slovakia $\left(20^{\circ} 06^{\prime} 05^{\prime}\right.$ E, $\left.49^{\circ} 13^{\prime} 10^{\prime \prime} \mathrm{N}\right)$. The samples were identified \\ according to the Key to European Usnea species (Randlane et al., 2009) and were \\ confirmed by other literature (Halonen et al., 1998; Matteucci et al., 2006; Tōrra \& \\ Randlane, 2007). \\ Usnic acid was extracted in a Soxhlet apparatus. About $57 \mathrm{~g}$ of thallus were grounded \\ and extracted with $750 \mathrm{ml}$ of diethyl ether within $5 \mathrm{~h}$. After extraction, the solution was \\ evaporated and the crude usnic acid was crystallized from absolute ethanol. Usnic acid \\ obtained was $503 \mathrm{mg}$. \\ $(+)$-Usnic acid, $(9 \mathrm{~b} R)$-2,6-diacetyl-3,8-dihydroxy-7,9,9b-trimethyl-3,9b-dihydro- \\ dibenzo $[b, d]$ furan-1 $(2 H)$-one: m.p. $=203-205^{\circ} \mathrm{C},[\alpha]_{20}^{\mathrm{D}}=+491.5^{\circ}\left(\mathrm{CHCl}_{3} ; \mathrm{c}=0.4\right),{ }^{1} \mathrm{H}$ \\ NMR $\left(\mathrm{CDCl}_{3}\right) 1.76(\mathrm{~s}, 3 \mathrm{H}), 2.11(\mathrm{~s}, 3 \mathrm{H}), 2.67(\mathrm{~s}, 3 \mathrm{H}), 2.68(\mathrm{~s}, 3 \mathrm{H}), 5.99(\mathrm{~s}, 1 \mathrm{H}), 11.02$ \\ $(\mathrm{s}, 1 \mathrm{H}), 13.30(\mathrm{~s}, 1 \mathrm{H}), 18.82(\mathrm{~s}, 1 \mathrm{H})$ \\ Solubilisation \\ Saturated solutions were prepared in $20 \mathrm{ml}$ vials by mixing excess powdered usnic acid \\ $(2 \mathrm{mg})$ with $2.5 \mathrm{ml}$ of deionised water or surfactant solution with a concentration \\ $\mathrm{c}=0.01 \mathrm{~mol} \cdot \mathrm{dm}^{-3}$ and stirring $(250 \mathrm{rpm})$ at a constant temperature $\mathrm{t}=25 \pm 1{ }^{\circ} \mathrm{C}$ \\ for 72 hours before filtering (Millipore, $0.22 \mathrm{~m}$ ) to remove unsolubilised usnic acid. \\ The extent of dissolution was determined by UV-spectroscopy. The filtered solution \\ $(1 \mathrm{ml})$ was diluted quantitatively with methanol in a $25 \mathrm{ml}$ volumetric flask. Absorbance \\ was measured at the optimum wavelength, $284 \mathrm{~nm}$, which was then compared \\ with the appropriate Beer's law plot for the drug in methanol. Water content \\ in the measured solution was low enough to allow the calibration with methanol \\ solutions to be used without correction. Measurements were performed in triplicate and \\ the results were averaged. Standard deviations were also calculated; considering \\ all sources of error, we estimate a maximum uncertainty in $s$ (solubility) of $10 \%$.
}

\section{RESULTS AND DISCUSSION}

Usnic acid was extracted from Usnea filipendula. The lichen substance was isolated as an $R$-enantiomer. Usnic acid obtained was $503 \mathrm{mg}$ from $57 \mathrm{~g}$ of thallus and it represents $0.88 \%$ of the dry lichen weight. Cansaran et al. (2006) reported similar amount of usnic acid in $U$. hirta $(0.68 \%)$ or U. longissima $(1.12 \%)$. 
Solubilities of usnic acid measured for deionised water, the surfactants solutions, $\boldsymbol{P}$ and $\boldsymbol{N}$, and their mixture, $\boldsymbol{P} / \boldsymbol{N}$, are depicted in Figure 3. The quantity $s$ represents the total compound solubility in micrograms of compound solubilised per millilitre of solution. The solubility value of usnic acid in water $\left(s_{\text {water }}=3.0 \mu \mathrm{g} / \mathrm{ml}\right)$ was similar as that determined previously, $5 \mu \mathrm{g} / \mathrm{ml}$ (Kristmundsdóttir et al., 2005).

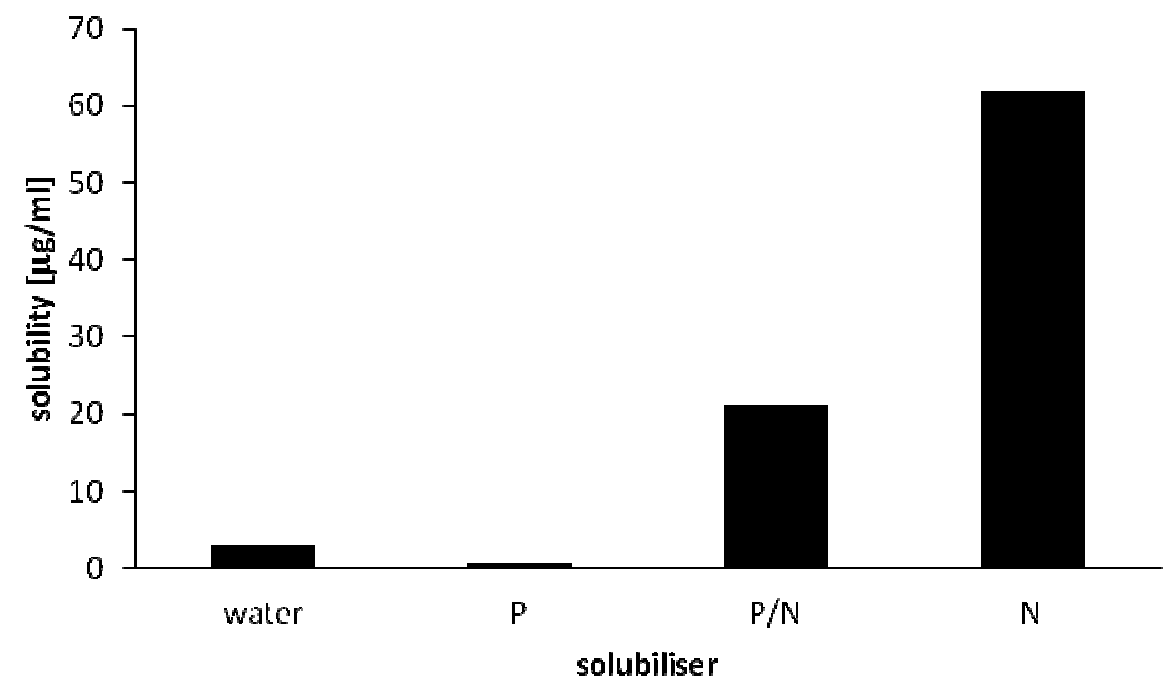

Figure 3 Solubility of usnic acid in water and aqueous micellar solutions

The influence of $\boldsymbol{P}, \boldsymbol{N}$ and $\boldsymbol{P} / \boldsymbol{N}$ was studied on solubilisation of lichen acid. $\boldsymbol{P}$ and $\boldsymbol{N}$ are compounds with similar chemical structure. Both compounds are gemini surfactants with two alkyl chains, which contain 10 carbon atoms, and with a spacer, whose length is 2 methylene groups. $\boldsymbol{N}$ is a bisammonium salt, a true gemini surfactant because it is symmetrical and contains two cationic polar head groups. $\boldsymbol{P}$ differs from $\boldsymbol{N}$. One cationic polar head group is replaced with phosphate, an anionic polar head group. $\boldsymbol{P}$ is a heterogemini surfactant.

$\boldsymbol{N}$ improves the total solubility of usnic acid in the solution $\left(s_{N}=61.7 \mu \mathrm{g} / \mathrm{ml}\right)$. A different situation was observed in the case of $\boldsymbol{P}\left(s_{\boldsymbol{P}}=0.6 \mu \mathrm{g} / \mathrm{ml}\right)$. The solubility of usnic acid in $\boldsymbol{P}$ solution was decreased in comparison to solubility in water. The possible reason of lower solubility of compound in $\boldsymbol{P}$ than in deionised water consists in the character of the aggregates of $\boldsymbol{P}$ formed in solution. $\boldsymbol{P}$ forms coacervates and vesicles besides micelles in aqueous solutions (Lukáč et al., 2011, Menger \& Peresypkin, 2001). The interaction between usnic acid and the coacervates/vesicles caused precipitation of $\boldsymbol{P}$ and the compounds were "glued" together. Solubility of usnic acid in $\boldsymbol{P} / \boldsymbol{N}$ is between the solubility in $\boldsymbol{P}$ and $\boldsymbol{N}\left(s_{\boldsymbol{P} / \boldsymbol{N}}=21.0 \mu \mathrm{g} / \mathrm{ml}\right)$. The synergisms between equimolar mixture of $\boldsymbol{P}$ an $\boldsymbol{N}$ were not observed in surface tension reduction efficiency, surface tension reduction effectiveness, and mixed micelle formation (Lukáč et al., 2011). In addition no synergisms were observed in solubilisation properties 
of $\boldsymbol{P} / \boldsymbol{N}$ on solubilisation of usnic acid; $s$ of lichen acid in solution of $\boldsymbol{P} / \boldsymbol{N}$ is lower than $s_{N}+s_{P} / 2$.

The influences of $\boldsymbol{P}, \boldsymbol{N}$ and their mixtures were also previously studied on solubilisation of rutin and griseofulvin (Lukáč et al., 2011). Some similarities between griseofulvin, rutin and usnic acid were observed. The compounds caused very low solubility in solutions of $\boldsymbol{P}$. The reason was explained previously. $\boldsymbol{N}$ increased the solubility of all compounds (usnic acid, griseofulvin and rutin). The difference is in the solubilisation influence of $\boldsymbol{P} / \boldsymbol{N}$ on solubilisation of the studied compounds. The solubility of usnic acid in $\boldsymbol{P} / \boldsymbol{N}$ is between its solubility in $\boldsymbol{P}$ and $\boldsymbol{N}$. However, griseofulvin and rutin were more soluble in $\boldsymbol{P} / \boldsymbol{N}$ than in $\boldsymbol{P}$ or $\boldsymbol{N}$ alone.

One has to take into account that the concentration of surfactants is well above their critical micelle concentrations $\left(\mathrm{cmc}_{N}=4.8 \times 10^{-3} \mathrm{~mol} \cdot \mathrm{dm}^{-3} ; \mathrm{cmc}_{P}=2.2 \times 10^{5} \mathrm{~mol} \cdot \mathrm{dm}^{-3}\right.$ (Lukáč et al., 2011)), so changes in the shape and structure of the micelles could play a distinctive role in the solubilisation of usnic acid.

\section{CONCLUSION}

In conclusion we can say that micellar solution of $N$ and $P / N$ increased the solubility of usnic acid in its aqueous solution in comparison with its solubility in deionised water. The solubility of lichen acid was more than 20 times higher in $N$ and 7 times higher in $\boldsymbol{P} / \boldsymbol{N}$ than the solubility of lichen acid in water. The solubility of usnic acid in an aqueous solution of $\boldsymbol{P}$ was decreased in comparison with the pure solvent.

\section{ACKNOWLEDGMENT}

This work was supported by the ESF grant no. NFP 26240120065.

\section{REFERENCES}

Bačkorová M, Bačkor M, Mikeš J, Jendželovský R, Fedoročko P. Variable responses of different human cancer cells to the lichen compounds parietin, atranorin, usnic acid and gyrophoric acid. Toxicol Vitro. 2011;25:37-44.

Bazin MA, Le Lamer AC, Decros JG, et al. Synthesis and cytotoxic activities of usnic acid derivatives. Bioorg Med Chem. 2008;16:6860-6866.

Cansaran D, Kahya D, Yurdakulol E, Atakol O. Identification and quantitation of usnic acid from the lichen Usnea species of Anatolia and antimicrobial activity. Z Naturforsch C. 2006;61:773-776. 
Cetin H, Tufan-Cetin O, Türk AO, et al. Insecticidal activity of major lichen compounds (-)- and (+)- usnic acid, against the larvae of house mosquito, Culex pipiens L. Parasitol Res. 2008;102:1277-1279.

da Silva Santos NP, Nascimento SC, Wanderley MSO, et al. Nanoencapsulation of usnic acid: An attempt to improve antitumor activity and reduce hepatotoxicity. Eur J Pharm Biopharm. 2006;64:154-160.

Einarsdóttir E, Groneweg J, Björnsdóttir GG, et al. Cellular mechanisms of the anticancer effects of the lichen compound usnic acid. Planta Med. 2010;76:969-974.

Halonen P, Clerc P, Goward T, Brodo IM, Wulff K. Synopsis of the genus Usnea (Lichenized Ascomycetes) in British Columbia, Canada. Bryologist. 1998;101:36-60.

Ingólfsdóttir K. Usnic acid. Phytochemistry. 2002;61:729-736.

Ingólfsdótir K, Chung GAC, Skúlason VG, Gissurason SR, Vilhelmsdóttir M. Antimycobacterial activity of lichen metabolites in vitro. Eur J Pharm Sci. 1998;6:141144 .

Kristmundsdóttir T, Aradóttir HA, Ingólfsdóttir K, Ögmundsdóttir HM. Solubilization of the lichen metabolite (+)-usnic acid for testing in tissue culture. J Pharm Pharmacol. 2002;54:1447-1452.

Kristmundsdóttir T, Jónsdóttir E, Ögmundsdóttir HM, Ingólfsdóttir K. Solubilisation of poorly soluble lichen metabolites for biological testing on cell lines. Eur J Pharm Sci. 2005;24:539-543.

Lira MCB, Ferraz MS, Da Silva DGVC, et al. Inclusion complex of usnic acid with $\beta$ cyclodextrin: characterization and nanoencapsulation into liposomes. J Incl Phenom Macro. 2009;64:215-224.

Lukáč M. Contribution to the genus Usnea (Parmeliaceae) in Slovakia III: apotheciate specimens of U. filipendula, U. florida, U. intermedia and U. subfloridana. Acta Facult Pharm Univ Comenianae. 2010;57:57-67.

Lukáč M, Mrva M, Fischer-Fodor E, et al. Synthesis and biological activity of dialkylphosphocholines. Bioorg Med Chem Lett. 2009;19:6346-6349.

Lukáč M, Prokipčák I, Lacko I, Devínsky F. Solubilisation of griseofulvin and rutin in aqueous micellar solutions of gemini and heterogemini surfactants and their mixtures. Eur J Pharm Sci. 2011;44:194-199.

Matteucci E, Munzi S, Potenza G. Unea workshop. Not Soc Lich Ital. 2006;19:129-137. 
Melgarejo M, Sterner O, Castro JV, Mollinedo P. More investigations in potent activity and relationship structure of the lichen antibiotic (+)-usnic acid and its derivate dibenzoylusnic acid. Revista Boliviana de Química. 2008;25:24-29.

Menger FM, Peresypkin AV. A combinatorially-derived structure phase diagram for 42 zwitterionic geminis. J Am Chem Soc. 2001;123:5614-5615.

Randlane T, Tōrra T, Saag A, Saag L. Key to European Usnea species. Bibl Lichenol. 2009;100:419-462.

Rangel-Yagui CO, Pessoa Jr A, Tavares LC. Micellar solubilisation of drugs. J Pharm Pharm Sci. 2005;8:147-163.

Ranković B, Mišić M, Sukdolak S. The antimicrobial activity of substances derived from lichens Physcia aipolia, Umbilicaria polyphylla, Parmelia caperata, and Hypogymnia physodes. World J Microbiol Biotechnol. 2008;24:1239-1242.

Segure-Sanchez F, Bouchemal K, Lebas G, Vauthier C, Santos-Magalhães NSS, Ponchel G. Elucidation of the complexation mechanism between $(+)$-usnic acid and cyclodextrins studied by isothermal titration calorimetry and phase-solubility diagram experiments. J Mol Rocognit. 2009;22:232-241.

Tay T, Türk AÖ, Yilmaz M, Türk M, Kivanç M. Evaluation of the antimicrobial activity of the acetone extract of the lichen Ramalina farinacea and its $(+)$-usnic acid, norstictic acid, protocetraric acid constituent. Z Naturforsch C. 2004;59:384-388.

Tōrra T, Randlane T. The lichen genus Usnea (lichenized Ascomycetes, Parmeliaceae) in Estonia with a key to the species in the Baltic countries. Lichenologist. 2007;39:415438 .

Ullah I, Baloch MK, Durrani GF. Solubility of lidocaine in ionic, nonionic, and zwitterionic surfactants. J Solution Chem. 2012;41:215-222.

Registered: February 15, 2012 Accepted: October 22, 2012

\author{
PharmDr. Miloš Lukáč, PhD \\ Comenius University in Bratislava \\ Faculty of Pharmacy \\ Department of Chemical Theory of Drugs \\ Kalinčiakova 8 \\ 832 32, Bratislava \\ Slovak Republic \\ lukac@fpharm.uniba.sk
}




\title{
SOLUBILIZÁCIA KYSELINY (+)-USNOVEJ VODNÝMI MICELÁRNYMI ROZTOKMI GEMINI A HETEROGEMINI TENZIDOV \\ A ICH EKVIMOLÁRNEJ ZMESI
}

\author{
Lukáč, M. - Prokipčák, I. - Lacko, I. - Devínsky F.
}

Univerzita Komenského v Bratislave, Farmaceutická fakulta, Katedra chemickej teórie liečiv

Bola študovaná solubilizácia prírodnej zlúčeniny, kyseliny (+)-usnovej, v micelárnych roztokoch gemini $\left(N, N^{\prime}\right.$-didecyl- $N, N, N^{\prime}, N^{\prime}$-tetrametyletán-1,2-diyldiamóniumdibromid) a heterogemini (decyl 2-[decyl(dimetyl)ammónio]etylfosfát) tenzidov a ich ekvimolárnej zmesi. Najvyššia rozpustnost' bola zaznamenaná v prípade gemini tenzidu. Diskutuje sa aj vzt'ah medzi synergizmom povrchových vlastností zmesi tenzidov a ich solubilizačnými vlastnost’ami.

Acta Fac. Pharm. Univ. Comen. LIX, 2012, (2), p. 36-43. 